\title{
SIMULATION OF 3D TRANSIENT FLOW PASSING THROUGH AN INTESTINAL ANASTOMOSIS BY LATTICE-BOLTZMANN METHOD
}

Context. Recently, the number of reconstructive operations on the digestive tract has significantly increased. Such operations have predictable negative consequences associated with disruptions of hydrodynamic processes in the anastomosis area. These negative consequences can be partially avoided by choosing anastomosis anatomical form based on mathematical modeling. Known mathematical models are cumbersome and do not allow to obtain results in real time. The proposed approach using lattice Boltzmann method allows solving this problem.

Objective. The purpose of the work is to develop a three-dimensional mathematical model of anastomosis for research of hydrodynamic parameters of fluids with complex structure in real time.

Method. The method of constructing and analyzing the mathematical model of anastomosis of the digestive tract based on lattice Boltzmann method is proposed. The method differs in that it provides simultaneous analysis of hydrodynamic parameters of the liquid and determines the nature of movement of fine-grained inclusions in the anastomosis area. The main stages of the method are the development of technology for determining the modeling area, discretization of the three-dimensional Boltzmann equation with the choice of lattice and the nature of the collision operator, taking into account the complex structure of the liquid; development of the technology of transition from the density distribution function to the distribution of pressure at the mesoscopic level, taking into account the properties of the liquid, the creation of the process of transforming the set of mesoscopic parameters into the macroscopic parameters of the liquid.

Results include determining the distribution of the velocity field in the anastomosis area to modify its geometry. The study of the influence of gravity on the nature of motion of fine-grained inclusions has been carried out. The quantitative characteristics of the delay of particles in the area of anastomosis, depending on the dynamic viscosity of the liquid, are determined.

Conclusions. The three-dimensional mathematical model discussed in this paper is based on the application of the lattice Boltzmann method for calculating the hydrodynamic parameters of the motion of fluid in the study area. The distinctive feature of the model is that it accounts for the complex nature of the liquid having fine-grained inclusions. The model allows determining the behavior of these inclusions and the field of speed with sufficient accuracy in real time.

Keywords: mathematical model, lattice method of Boltzmann, anastomosis simulation.

\section{NOMENCLATURE}

$x, y, z$ - continuous Cartesian coordinates of threedimensional space;

$t$ - time of simulation;

$v$ - elocity of the elemental volume of liquid at the mesoscopic level;

$v_{\omega}$ - vector of velocity of the elemental fluid volume in the node $\omega$;

$f(x, y, z, v, t)$ - density distribution function;

$f_{\omega}-$ density distribution function at node $\omega$;

$f^{(e q)}(x, y, z, v, t)$ - equilibrium density distribution function;

$\tau$ - relaxation factor in the direction $f^{(e q)}(x, y, z, v, t)$;

$\delta$ - parameter of fine-grained inclusions;

$c_{s}$ - speed of sound propagation in the studied area;

$\lambda$ - kinematic viscosity;

$\eta$ - dynamic viscosity;

$\rho_{l}-$ liquid density;

$p$ - pressure at the outlet; $n$ - number of fine-grained inclusions in the simulation area;

$d$ - diameter of the fine-grained inclusion;

$\rho_{p}$ - density of fine-grained inclusions;

$u$ - vector of macroscopic velocity;

$w_{\omega}$ - weight ratio in the node $\omega$;

$\Delta t, \Delta x, \Delta y, \Delta z-$ steps in time and space.

\section{INTRODUCTION}

Life science nowadays is a rapidly developing area of research. The urgent need for obtaining new results in this field of knowledge arose long ago but was constrained by the considerable complexity of research objects. Biological processes, which, as a rule, are the main objects of the study of life sciences, are characterized by variability, which is caused by the dependence on many parameters. However, the complexity of measuring these parameters is another important challenge that impedes progress in this area. In most cases, this complexity is due to the fact that there are difficulties with direct access to the object of measurement. Another negative factor is that the measuring instruments significantly affect the investigated process. Therefore, in this area, simulation has been and remains one of the most effective methods of research. 
This work describes the mathematical modeling of fluid motion with fine-grained inclusions through anastomoses in the lower section of the human digestive tract. The importance of this study is based on the fact that this section of the digestive tract is characterized by high peristaltic activity and, accordingly, high sensitivity to surgical intervention. A traditional approach, in this case, is to solve a boundary value problem based on a system of equations containing the Navier-Stokes equation and the flow continuity equation. The process of solving this nonstationary nonlinear boundary-value problem is cumbersome and requires a large amount of computational resources since rapid change in parameters requires a high degree of discretization and imposes additional conditions on the convergence of computational methods. Therefore, in recent years, alternative approaches have been developing rapidly using neural networks, cellular automata and other means of description for complex processes. Among the abovementioned methods, the method based on solving the lattice Boltzmann equation in each node of the discrete area is important and is called the lattice Boltzmann method.

\section{PROBLEM STATEMENT}

This work describes the development and research of a mathematical model of fluid motion with fine-grained inclusions through the anastomosis area of the lower part of the digestive tract. The objective functions of such a model are to determine the velocity field, the pressure distribution and the characteristics of sticking of finegrained inclusions in the anastomosis area. To simplify the simulation process and achieve the possibility of mathematical modeling in real time, the lattice Boltzmann method is applied. The Boltzmann equation for $3 \mathrm{D}$ simulation describes the probability of the fact that the elemental volume of a liquid at a time $t$ will be in a cube with a center at the point with the coordinates $(x, y, z)$ and the lengths of the edges $d x, d y, d z$, and the velocity of the motion of this elemental volume will be in the range from $v$ to $d v[1]$.

In general, the equation is represented by the expression:

$$
\begin{gathered}
\frac{\partial f(x, y, z, v, t)}{\partial t}+v\left(\frac{\partial f(x, y, z, v, t)}{\partial x}+\frac{\partial f(x, y, z, v, t)}{\partial y}+\right. \\
\left.+\frac{\partial f(x, y, z, v, t)}{\partial z}\right)=\Omega(f(x, y, z, v, t)) .
\end{gathered}
$$

The function of the right-hand side of the equation (1) is called the collision operator. The operator $\Omega(f(x, y, z, v, t))$ describes the nature of the collisions of elemental volumes during the movement of the fluid. In general, the operator of collisions is given by the following expression:

$$
\Omega(f(x, y, z, v, t))=\frac{\delta}{\tau}\left(f(x, y, z, v, t)-f^{(e q)}(x, y, z, v, t)\right) .
$$

where $\tau-$ a constant that determines the time scale required to establish a local equilibrium, $\delta$ - a parameter whose value depends on the presence and the compacted location of the fine-grained inclusions in the node at the moment of collision, $f^{(e q)}(x, y, z, v, t)$ - equilibrium function of the Maxwell-Boltzmann density distribution.

Equations (1) and (2) describe the fluid behavior at each point of the investigated area at mesoscopic level. Therefore, there is a problem of transition from mesoscopic to macroscopic level, on which the fluid parameters are represented by the velocity field and the pressure distribution.

For such a transition, we will apply a Chapman-Enskog expansion [2] adapted to the conditions of this model, which forms the connection between the kinematic viscosity and the Boltzmann equation parameters:

$$
\lambda=\frac{(2 \tau-\Delta t \delta) c_{s}^{2}}{2 \delta} .
$$

The Chapman-Enskog expansion allows replacing the solution of a boundary-value problem based on the NavierStokes equation by solving a set of Boltzmann equations, each of which describes the dynamics of the movement of elementary fluid volumes in the nodes of a discrete lattice covering the study area.

\section{LITERATURE REVIEW}

There are two main approaches for simulating the flow of fluid, which use the macroscopic and mesoscopic level of process description. A traditional approach to obtaining fluid flow parameters is involves applying numerical methods for solving a boundary value problem on the basis of the Navier-Stokes equation [3]. Methods of finite differences [4], methods of finite elements [5] and methods of finite volumes are widely used [6]. These methods have common disadvantages related to stability and convergence, since through discretization of the corresponding equations these methods are reduced to the solution of the system of linear algebraic equations by iterative methods. Despite the possibility of achieving high accuracy of the solution, it is often difficult to achieve the convergence of the iterative process, provided the variability of the input data and in areas of complex geometry. Unfortunately, multiple physical processes, including those processes occurring in biological objects, have precisely such characteristics [7]. The disadvantages of numerical methods also include the complexity of parallelizing the process of solving the boundary value problem. To overcome these and some other disadvantages, alternative approaches were explored. The lattice Boltzmann method, which describes the movement of elemental volumes of liquid at the mesoscopic level, is one of the most popular approaches. The first publications on the lattice Boltzmann method have a nearly 30-year history [8]. During this time, the method received a significant theoretical basis and became one of the popular methods of simulating fluid motion in biological objects [9]. The reason for the high popularity of lattice Boltzmann method is the fact that the calculations of fluid flow parameters are performed locally for each discrete point, which allows the use of parallel algorithms [10]. The method can also be 
effectively applied to simulate three dimensional areas with complex geometry [11] and to take into account the complex structure of the liquid [12]. These properties of the lattice Boltzmann method are the basis for choosing tools to study of anastomosis of the digestive tract [13, 14].

\section{MATERIALS AND METHODS}

The mathematical model of ileum anastomosis of the human digestive tract is considered in this paper. The shape of a threedimensional area has the form of a rectangular parallelepiped with an internal cavity that corresponds to the investigated fragment of the ileum. The geometry of this anastomosis is based on the experience of practicing surgeons. The general view of the study area is shown in fig. 1 .

Through the inner cavity flows a fluid that has a complex structure. Parameters of this fluid vary during the computational experiment in the following ranges: liquid density $\rho_{l}\left[\mathrm{~kg} / \mathrm{m}^{3}\right]: 100 \div 1000$; dynamic viscosity of the liquid $\eta[\mathrm{Pa} \mathrm{s}]: 10^{-3} \div 100$; speed of the fluid through the inlet $u[\mathrm{~m} / \mathrm{s}]: 0 \div 0.09$; outlet pressure $p[\mathrm{~Pa}]: 10^{5}$; number of fine-grained inclusions in the field of simulation [Pcs]: $1 \div 1000$; diameter of the fine-grained inclusion $d[\mathrm{~m}]$ : $10^{-4} \div 10^{-3}$; density of fine-grained inclusions $\rho_{p}\left[\mathrm{~kg} / \mathrm{m}^{3}\right]$ : $1000 \div 1500\left[\mathrm{~kg} / \mathrm{m}^{3}\right]$.

Parameters of the mathematical model vary in the following range: maximum number of time steps $m_{\max }$ : $1 \div 100$; number of nodes in the discretizing grid $\left|\Omega\left(x_{i_{\max }}, y_{j_{\max }}, z_{k_{\max }}\right)\right|: 2000500000$; maximum step in the time layer [s]: 0.01 .

The first step in the implementation of the mathematical model of fluid motion in the area, shown in fig. 1 , is to discretize the area. In this case, the rectangular parallelepiped $G$ is covered by a three-dimensional lattice $\Omega$, the nodes $\omega\left(x_{i}, y_{j}, x_{k}\right)$ of which are elements of the set:

$$
\Omega=\left\{\omega\left(x_{i}, y_{j}, z_{k}\right) \mid i=\overline{0, i_{\max }-1}, j=\overline{j_{\max }-1}, k=\overline{0, k_{\max }-1}\right\} .
$$

Each of the nodes belongs to one or three types: "wet" nodes or nodes in the fluid area, "dry" nodes or nodes of the environment and boundary nodes constituting the limiting surface.

We describe the evolution of elementary fluid volumes in the nodes of the area by a system of equations:

$$
\frac{\partial f_{\omega}}{\partial t}+v_{\omega} \nabla f_{\omega}=\frac{1}{\tau}\left(f_{\omega}-f_{\omega}^{(e q)}\right), \omega=0,1,2, \ldots,|\Omega|-1,
$$

where $f_{\omega}-$ density distribution function in the direction of the mesoscopic velocity vector $v_{\omega}, f_{\omega}^{(e q)}-$ an equilibrium density distribution function corresponding to the vector $v_{\omega}$.

We discretize the system of equations (3) over time and spatial variables for numerical solutions. Let us represent the vector of the mesoscopic velocity of the elementary volume of a liquid at the point $\omega$ by the tuple $v_{\omega}=\left(v_{\omega_{x}}, v_{\omega_{y}}, v_{\omega_{z}}\right)$ of its projections on the axis $x, y, z$.

Marking the time step as $\Delta t$, and spatial steps for each coordinate as $\Delta x_{\omega}=v_{\omega_{x}} \Delta t, \Delta y_{\omega}=v_{\omega_{y}} \Delta t, \Delta z_{\omega}=v_{\omega_{z}} \Delta t$ we can produce the discrete version of the Boltzmann equation:

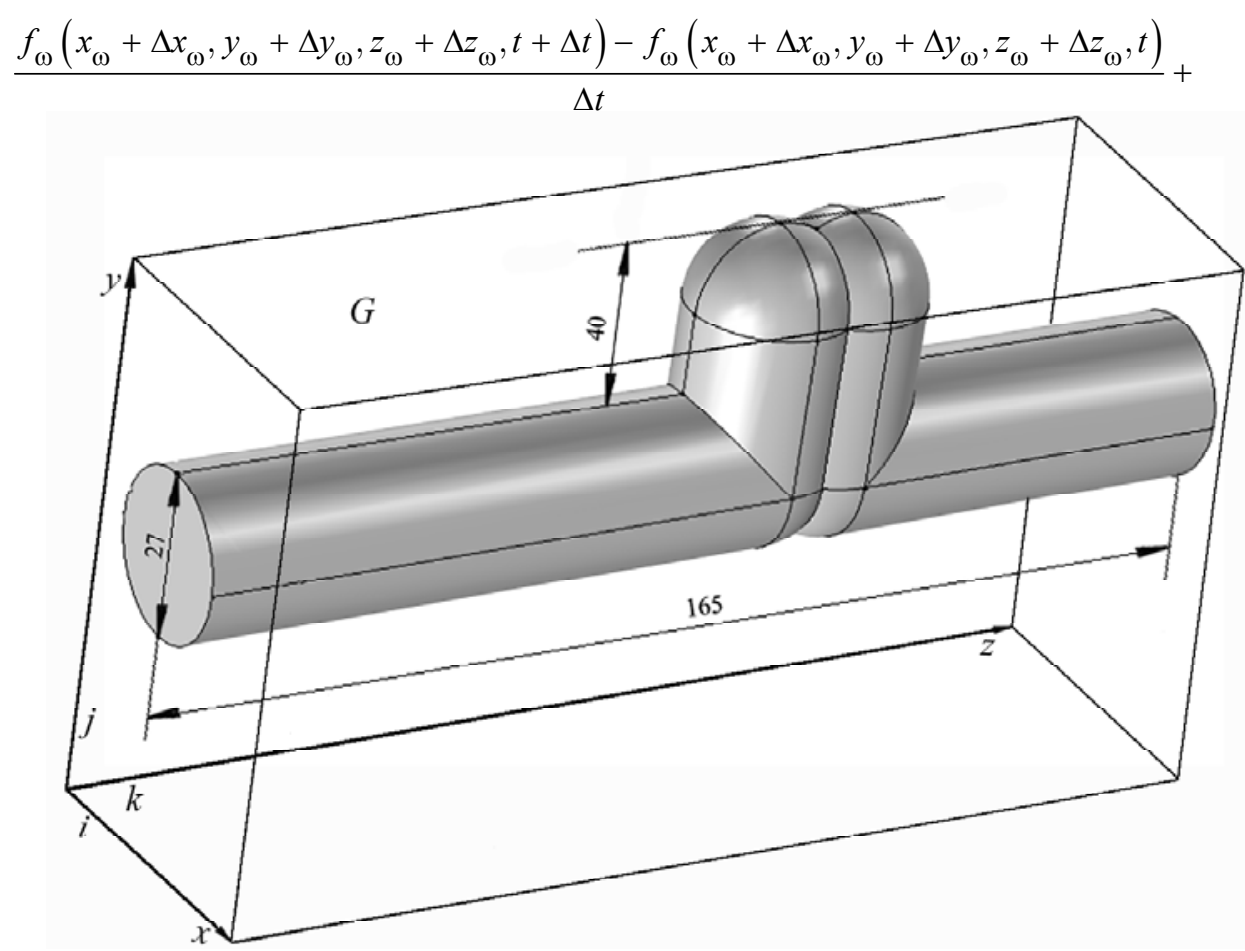

Figure 1 - General view and geometric dimensions of "side-to-side" anastomosis 


$$
\begin{gathered}
+\frac{f_{\omega}\left(x_{\omega}+\Delta x_{\omega}, y_{\omega}, z_{\omega}, t\right)-f_{\omega}\left(x_{\omega}, y_{\omega}, z_{\omega}, t\right)}{\Delta x_{\omega}}+\frac{f_{\omega}\left(x_{\omega}, y_{\omega}+\Delta y_{\omega}, z_{\omega}, t\right)-f_{\omega}\left(x_{\omega}, y_{\omega}, y_{\omega}, t\right)}{\Delta y_{\omega}}+ \\
+\frac{f_{\omega}\left(x_{\omega}, x_{\omega}, z_{\omega}+\Delta z_{\omega}, t\right)-f_{\omega}\left(x_{\omega}, y_{\omega}, z_{\omega}, t\right)}{\Delta z_{\omega}}=-\frac{f_{\omega}\left(x_{\omega}, y_{\omega}, z_{\omega}, t\right)-f_{k}^{(e q)}\left(x_{\omega}, y_{\omega}, z_{\omega}, t\right)}{\tau} .
\end{gathered}
$$

Let's set $\Delta x_{k}=\Delta t=1$. Then equation (4) will look like:

$$
\begin{aligned}
f_{\omega}\left(x_{\omega}+\Delta x_{\omega}, y_{\omega}+\Delta y_{\omega}, z_{\omega}+\Delta z_{\omega}, t+\Delta t\right)-f_{\omega}\left(x_{\omega}, y_{\omega}, z_{\omega}, t\right)= \\
=-\frac{1}{\tau}\left(f_{\omega}\left(x_{\omega}, y_{\omega}, z_{\omega}, t\right)-f_{\omega}^{(e q)}\left(x_{\omega}, y_{\omega}, z_{\omega}, t\right)\right),
\end{aligned}
$$

The simulation of the process of solving equation (5) is carried out in two stages.

1. Collision at the node $\omega$ :

$$
\begin{gathered}
\tilde{f}_{\omega}\left(x_{\omega}, y_{\omega}, z_{\omega}, t+\Delta t\right)=f_{\omega}\left(x_{\omega}, y_{\omega}, z_{\omega}, t\right)- \\
-\frac{1}{\tau}\left(f_{\omega}\left(x_{\omega}, y_{\omega}, z_{\omega}, t\right)-f_{\omega}^{(e q)}\left(x_{\omega}, y_{\omega}, z_{\omega}, t\right)\right) .
\end{gathered}
$$

2. Distribution of the obtained value of the distribution function $\tilde{f}_{\omega}\left(x_{\omega}, y_{\omega}, z_{\omega}, t+\Delta t\right)$ for the moment of time $t+\Delta t$ to the neighboring nodes of the grid:

$$
f_{\omega}\left(x_{\omega}+\Delta x_{\omega}, y_{\omega}+\Delta y_{\omega}, z_{\omega}+\Delta z_{\omega}, t+\Delta t\right)=\tilde{f}_{k}\left(x_{\omega}, y_{\omega}, z_{\omega}, t+\Delta t\right) .
$$

Neighborhood relationship identifies those nodes for which the interaction with the current node $\omega$ is given. For this model, the nature of such connections is unified and is called D3Q19 (fig. 2).

Equation (6) includes an equilibrium density distribution function for a node $\omega$.

We apply an expression for this function, which was first proposed in the work [15].

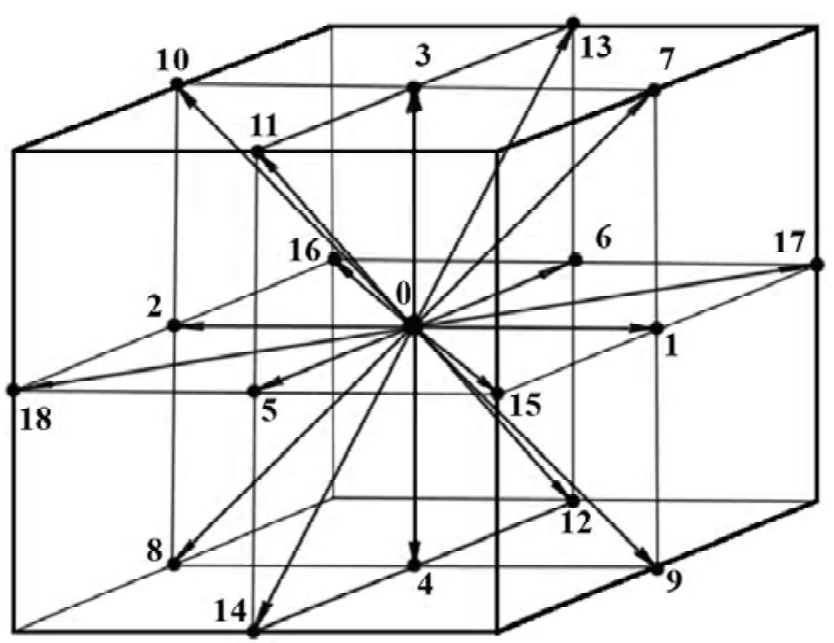

Figure 2 - The structure of the connections for an arbitrary node on the grid D3Q19

$$
f_{\omega}^{(e q)}=w_{\omega} \rho\left[1+\frac{3}{c_{s}^{2}} v_{\omega} \cdot u+\frac{9}{2 c_{s}^{4}}\left(v_{\omega} \cdot u\right)^{2}-\frac{3}{2 c_{s}^{2}}(u \cdot u)\right],
$$

where $c_{s}=\frac{\Delta x}{\Delta t}-$ constant that determines the speed of the activity in the lattice.

We will determine scaling factors $w_{\omega}$ using the expression

$$
\omega_{k}=\left\{\begin{array}{l}
1 / 3, \omega=0 \\
1 / 18, \omega=1,2,3,4,5,6, \\
1 / 36, \omega=7,8,9, \ldots, 18,
\end{array}\right.
$$

for each node velocity

$$
v_{\omega}=\left\{\begin{array}{l}
(0,0,0), k=0, \\
( \pm 1,0,0) c,(0, \pm 1,0) c,(0,0, \pm 1) c, k=1,2,3,4,5,6, \\
( \pm 1, \pm 1,0) c,( \pm 1,0, \pm 1) c,(0, \pm 1, \pm 1) c, k=7,8,9, \ldots 18
\end{array}\right.
$$

Considering the fact that the fluid pressure $p_{\omega}$ in each node $\omega$ is related to the distribution function through the expression $p_{\omega}=c_{s}^{2} f_{\omega}$, we can write the expression for pressure in the equilibrium state:

$p_{\omega}^{(e q)}=c_{s}^{2} f_{\omega}^{(e q)}=w_{\omega}\left\{p+p_{0}\left[3 \frac{v_{\omega} \cdot u}{c_{s}^{2}}+\frac{9}{2} \frac{\left(v_{\omega} \cdot u\right)^{2}}{c_{s}^{4}}-\frac{3}{2} \frac{u^{2}}{c_{s}^{2}}\right]\right\}$

where $p_{0}=c_{s}^{2} \rho$ - average pressure.

Let's modify equation (5), replacing $f_{\omega}$ with $p_{\omega}$

$$
\begin{gathered}
p_{\omega}\left(x_{\omega}+\Delta x_{\omega}, y_{\omega}+\Delta y_{\omega}, z_{\omega}+\Delta z_{\omega}, t+\Delta t\right)-p_{\omega}\left(x_{\omega}, y_{\omega}, z_{\omega}, t\right)= \\
=-\frac{1}{\tau}\left(p_{\omega}\left(x_{\omega}, y_{\omega}, z_{\omega}, t\right)-p_{\omega}^{(e q)}\left(x_{\omega}, y_{\omega}, z_{\omega}, t\right)\right), \quad \text { (9) }
\end{gathered}
$$

Having solved the equation according to the scheme (6), (7), we can determine the macroscopic parameters of the pressure distribution and velocity fields from the equations:

$$
p=\sum_{\omega} p_{\omega}, u=\frac{1}{p_{0}} \sum_{\omega} v_{\omega} p_{\omega}
$$

\section{EXPERIMENTS}

The main results of the simulations were obtained on the example of the classical spatial form of anastomosis, 
which is shown in fig. 1. During the simulation one of the important tasks was to determine the distribution of pressure and velocity fields in the study area, depending on the fluid parameters. Such research allows to determine areas with extreme values of measured parameters and, based on this information, formulate recommendations for choosing the geometric form of anastomosis, which would allow to critically reduce the risk of the so-called "blind bags" or unwanted additional cavities.

The second group of experiments aimed to determine the trajectories and the behavior of fine-grained inclusions in the fluid under study. The main parameters of the variation during these experiments were the size and number of particles, which can simultaneously be in the area we are investigating. To simplify the calculations, it is assumed that all the fine-grained inclusions have the same shape, size and density. The tasks of this group of studies were to determine the areas of accumulation of particles, which indicate the possibility of occurrence of stagnant phenomena in the application of a particular form of anastomosis.

The study used self-created software written in the algorithmic programming language Python in the environment PyCharm. Third-party software in the form of additional modules pyLBM-0.2.1, numpy-1.12.1, Cython0.25.2, mpi4py-2.0.0, matplotlib-2.0.2 and others was also used. To prepare geometric forms of anastomosis, the package for creating 3D computer graphics Blender-2.78 was used.

\section{RESULTS}

The main results are obtained through the creation and study of a mathematical model of fluid motion with finegrained inclusions in a three-dimensional complex domain. To determine the fluid parameters, a technology based on the application of the Boltzmann lattice method was used. The created model allows to get parameters of speed of a liquid with accuracy $\varepsilon<10^{-5} \mathrm{~m} / \mathrm{s}$. However, the great variability of biological processes makes absolute values of field velocities less informative when evaluating biological phenomena. The simulation results presented in a graphical form allow us to qualitatively evaluate the field of fluid velocities and draw conclusions about the correction of the form of anastomosis. For example, the velocity field shown in fig. 3, displays areas that require shape correction.

The trajectory of the motion of fine-grained inclusions at each time of the modeling time was determined as the result of the action on the particle of three forces: the interaction force of the particle with the liquid, the force that is the result of collision of this particle with the adjacent particles and the force of gravity. Studies have shown a significant dependence of the location of anastomosis in space on the trajectory of fine-grained inclusions. We can observe on fig. 4 difference of arrangement of particles at different positions of anastomosis in relation to gravity. Parameters of this experiment: total simulation time $t_{\max }=600 \mathrm{~s}$; moment of time, shown in figure $4-$ $t_{\text {cur }}=325 \mathrm{~s}$. Number of particles in the research area
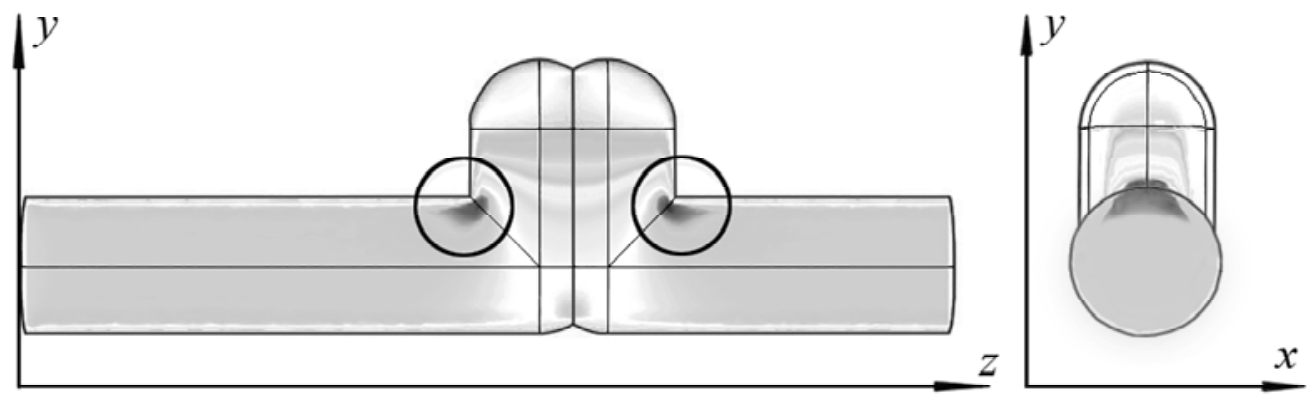

Figure 3 - Critical areas of "side-to-side" anastomosis

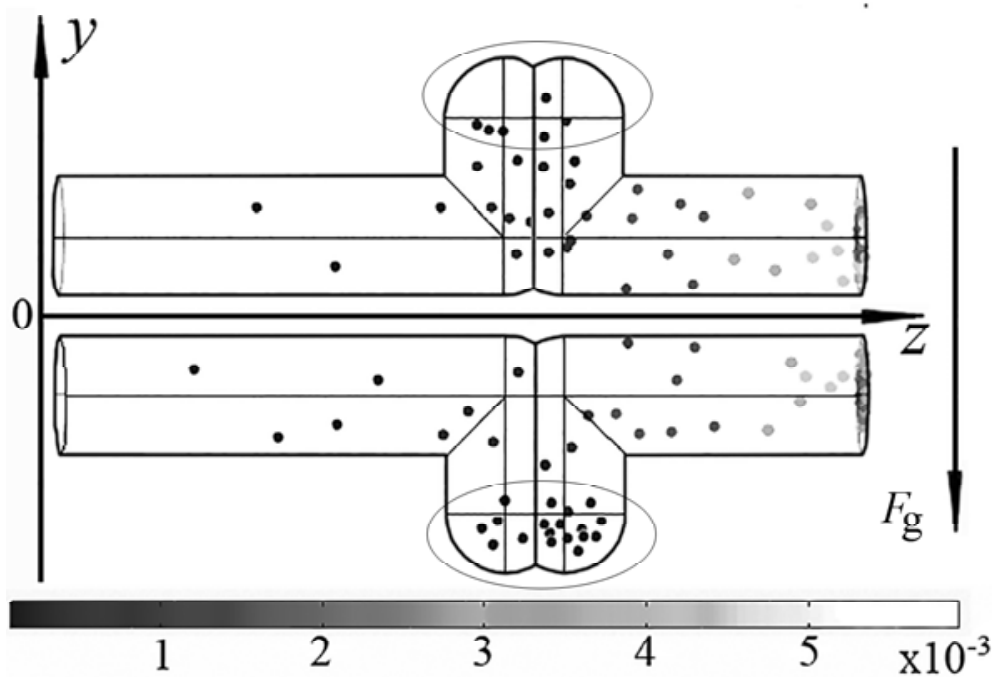

Figure 4 - Dependence of the distribution of fine-grained inclusions on the position of the area 
$n=100$ Pcs; fluid density $\rho_{l}=1000 \mathrm{~kg} / \mathrm{m}^{3}$; particle density $\rho_{p}=1500 \mathrm{~kg} / \mathrm{m}^{3}$; particle size $d=10^{-3} \mathrm{~m}$. The distribution of particles at speeds is determined by the tint in $\mathrm{m} / \mathrm{s}$.

From the picture, it is obvious that the position of anastomosis affects the nature of the movement of finegrained inclusions, which can lead to stagnant phenomena in the anastomosis area. The nature of such influence depends essentially on the relationship between the density of the liquid and the density of the fine-grained inclusions, as well as the dynamic viscosity of the liquid, which can vary in a certain range. Figure 5 shows the dependence of the percentage of "sticking" of fine-grained inclusions, depending on the dynamic viscosity of the liquid. This study used fine-grained inclusions with size $d=10^{-3} \mathrm{~m}$ and density $\rho_{p}=1500 \mathrm{~kg} / \mathrm{m}^{3}$.

\section{DISCUSSION}

Simulations of fluid movement in the digestive tract of a person have a certain history, both in our country [16] and abroad [17]. Relevant mathematical models have allowed a qualitative assessment of the phenomena studied. However, the high variability of biological processes and the complexity of geometric shapes did not allow practical application of simulation results. The current level of development of computer technology and new methods of parallel computing have significantly increased the accuracy and reduced computation time due to the parallel processing of large data sets. The approach to the simulation of physical processes proposed in this paper has a number of advantages, among which is the important fact that the complexity of the mathematical model does not depend on the shape of the area. The reason for such an effect is the locality of the calculations, the nature of which is unified for each node of the discretized area of the study. In addition, the local nature of data exchange with neighboring nodes in the area lies at the heart of creating algorithms that have the property of natural parallelism. The mentioned factors allowed to build software with the ability to interact online in real time. The advantage of this approach is accounting for the fine-grained inclusions in the liquid. This significantly increased the adequacy of the mathematical model and made it possible to estimate the effect of gravity on the processes associated with undesired accumulation of these inclusions

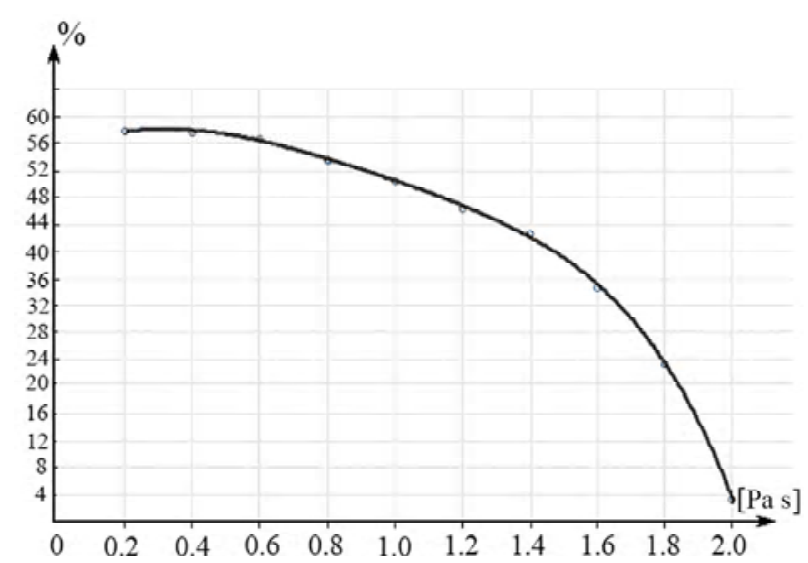

Figure 5 - The percentage of "sticking" of fine-grained inclusions in certain areas of anastomosis. The practical value of this work is that by applying these research results it was possible to reduce $10-15 \%$ negative consequences of reconstructive operations on the digestive tract. The further direction of research includes increasing area of modeling and accounting for peristaltic oscillations, as the main source of fluid flow through the area of anastomosis. A separate aspect of the study is the consideration of possible peristaltic oscillations of the actual anastomosis area, which has not yet been used in practice and has not been considered in mathematical modeling. In the research plan, there is also the construction and research of models of reconstructive operations on different parts of the digestive tract.

\section{CONCLUSIONS}

The work involves the development and research of a mathematical model that describes the parameters of the functioning of anastomosis in the lower parts of the human digestive tract. The importance of these studies is due to a significant increase in such operations and the presence of negative consequences of surgical intervention. The proposed approach to the description of the motion of the fluid in the anastomosis area is based on the use of lattice Boltzmann method. Due to the use of this method and the application of modern software development technologies, the adequacy of the mathematical model in comparison with the traditional mathematical models based on the solution of the boundary value problem based on the Navier-Stokes equation and the flow continuity equation is significantly increased. Experiments have shown that this method allows us to calculate the volume velocity in anastomosis zone with an accuracy of $\varepsilon<10^{-5} \mathrm{~m} / \mathrm{s}$ for the geometric parameters of the area and physical parameters of the fluid given in the work for 2-3 minutes.

A feature of the proposed mathematical model is the fact that it takes into account the complex nature of the liquid, which includes fine-grained impurities. The character of the behavior of these impurities in the field of anastomosis, depending on the dynamic viscosity of the fluid, is investigated. The second advantage of the proposed approach is the possibility to reduce the simulation time by applying parallel algorithms for calculating local mesoscopic fluid parameters for each node in the investigated area. Thus, for the first time it became possible to obtain the results of model experiments using three-dimensional mathematical modeling in real time.

\section{ACKNOWLEDGMENTS}

This work was performed as part of program "Development, research and implementation into the surgical practice some new types of anastomoses in the digestive canal" of cooperation between National Technical University of Ukraine "Igor Sikorsky Kyiv Polytechnic Institute" and Bogomolets National Medical University.

\section{REFERENCES}

1. Nesterenko B. B. Mathematical simulation for parallel asynchronous methods of boundary value problems of mathematical physics / B. B. Nesterenko, M. A. Novotarskiy // IMACS World Congress: $16^{\text {th }}$ international conference, Lausanne, 21-25 August 2000: proceedings. - Ecole Polytechnique Federale de Louzanne, 2000. - P. 116-122. 
2. Rosenau $\mathrm{Ph}$. Extending hydrodynamics via the regularization of the Chapman-Enskog expansion / Ph. Rosenau // Physical Review A. - 1989. - Vol. 40, Issue 12. - P. 7193-7196. DOI: 10.1103/ PhysRevA.40.7193.

3. Temam R. Navier-stokes equations: theory and numerical analysis

4. Mitchell A. R. The finite difference method in partial differential equations / A. R. Mitchell, D. F. Griffiths. - New York: John Wiley, 1980. $-272 \mathrm{p}$.

5. Girault V. Finite Element Methods for Navier-Stokes Equations: Theory and Algorithms / V. Girault, P-A. Rivart. - Berlin: SpringerVerlag, 1980. - 375 p. DOI: 10.1007/978-3-642-61623 5.

6. Versteeg H. K. An Introduction to Computational Fluid Dynamics: The Finite Volume Method / H. K. Versteeg, M. Malalasekera. -

7. Vilsmeier R. Finite volumes for complex applications II: problems and perspectives / R. Vilsmeier, F. Benkhaldoun, D. Hänel. Middlesex: Hermes Science Publications, 1999. - 887 p. G. Doolen // Annual Review of Fluid Mechanics. - 1998. Vol. 30. - P. 329-364. DOI: 10.1146/annurev.fluid.30.1.329.

9. Jahanshaloo L. An overview of boundary implementation in lattice Boltzmann method for computational heat and mass transfer / L. Jahanshaloo, N. A. C. Sidik, A. Fazeli // International Communications in Heat and Mass Transfer. - 2016. - Vol. 78, Issue 11. - P. 1-12. DOI: 10.1016/ j.icheatmasstransfer.2016.08.014.

10. Tan J. A parallel fluid solid coupling model using LAMMPS and Palabos based on the immersed boundary method / J. Tan, T. Sinno, S. Diamond, [Electronic resource]. - https://arxiv.org/ abs/1704.04551. / R. Temam. - Amsterdam: North-Holland, 1984. - 408 p. London: Paerson education Ltd., 1995. - 511 p.

8. Chen S. Lattice Boltzmann method for fluid flows / S. Chen,

11.Chen D. J. Immersed boundary method based Lattice Boltzmann method to simulate 2D and 3D complex geometry flows / D. J. Chen, K. H. Lin, C. A. Lin // International Journal of Modern Physics C. - 2007. - Vol. 18, Issue 4. - P. 585-594. DOI: 10.1142/ S0129183107010826.

12. Aidun C. K. Lattice-Boltzmann Method for Complex Flows / C. K. Aidun, J. R. Clausen // Annual Review of Fluid Mechanics. 2010. - Vol. 42, Issue 1. - P.439-472. DOI: 10.1146/annurevfluid-121108-145519.

13. Нестеренко Б. Б. Математичне моделювання перистальтичних процесів на основі решітчастого рівняння Больцмана / Б. Б. Нестеренко, М. А. Новотарський // Математичне та комп'ютерне моделювання: технічні науки. - Кам'янець-Подільський : Кам'янець-Подільський національний університет, 2014. - Вип. 11. - С. 96-107.

14. Новотарський М. А. Моделювання руху рідини у тривимірній області з рухомими границями / М. А. Новотарський, Е. Б. Бронфман // Вісник НТУУ «КПІ». Інформатика, управління та обчислювальна техніка : зб. наук. пр. - К. : Век+, 2016. - № 64. - C. 100-105.

15. He X. Lattice Boltzmann Model for the Incompressible NavierStokes Equation / X. He, L.-S. Luo // Journal of Statistical Physics. - 1997. - Vol. 88, № 3-4. - P. 927-944. DOI: 10.1023/ B:JOSS.0000015179.12689.e4.

16. Жученко С. П. Принципы построения математической модели перистальтики тонкой кишки / С. П. Жученко, Б. Б. Нестеренко. - К. : Ін-т математики, Вып. 87.64, 1987. - 52 с.

17. Macagno E. O. Modeling the effect of wall movement on absorption in the intestine / E. O. Macagno, J. Christensen, C. L. Lee // Am. J. Physiol. Gastrointest Liver Physiol. - 1982. Vol. 243. - P. G541-G550.

Article was submitted 22.09.2017 After revision 02.11.2017.

Новотарський М. А. ${ }^{1}$, Стіренко С. Г., ${ }^{2}$ Гордієнко Ю. Г. ${ }^{3}$

'Д-р техн. наук, професор кафедри обчислювальної техніки, Технічний університет України «Київський політехнічний інститут імені Ігоря Сікорського»

${ }^{2}$ Д-р техн. наук, професор, завідувач кафедри обчислювальної техніки, Технічний університет України «Київський політехнічний інститут імені Ігоря Сікорського»

${ }^{3}$ Д-р физ.-мат. наук, професор кафедри обчислювальної техніки, Технічний університет України «Київський політехнічний інститут імені Ігоря Сікорського»

МАТЕМАТИЧНЕ МОДЕЛЮВАННЯ ТРИВИМІРНОГО НЕСТАЦІОНАРНОГО ПОТОКУ ЧЕРЕЗ АНАСТАМОЗ ТРАВНОГО ТРАКТУ РЕШІТЧАСТИМ МЕТОДОМ БОЛЬЦМАНА

Актуальність. Останнім часом істотно зросла кількість реконструктивних операцій на травному тракті людини. Результати таких операцій мають прогнозовані негативні наслідки, що пов'язані з порушеннями гідродинамічних процесів у зоні анастомозу. Ці негативні наслідки можливо частково усунути шляхом вибору форми анастомозу на основі математичного моделювання. Відомі математичні моделі є громіздкими і не дозволяють отримувати результати в реальному масштабі часу. Запропонований в роботі підхід 3 використанням решітчастого методу Больцмана дозволяє вирішити цю проблему.

Метою роботи є розробка тривимірної математичної моделі області анастомозу для дослідження з достатньою точністю гідродинамічних параметрів рідини зі складною структурою в реальному масштабі часу.

Метод. Запропоновано метод побудови та аналізу математичної моделі анастомозу травного тракту на основі решітчастого методу Больцмана. Метод відрізняється тим, що забезпечує одночасний аналіз гідродинамічних параметрів рідини та визначає характер руху дрібнозернистих включень у зоні анастомозу. Основні етапи методу: розробка технології задавання області моделювання, дискретизація тривимірного рівняння Больцмана з вибором решітки та характеру оператора колізій, який враховує складну структуру рідини; розробка технології переходу від функції розподілу густини до розподілу тиску на мезоскопічному рівні 3 урахуванням особливостей властивостей рідини, перехід від мезоскопічних до макроскопічних параметрів рідини.

Результати моделювання включають визначення розподілу поля швидкостей в зоні анастомозу з метою модифікації його геометрії. Проведено дослідження впливу сили тяжіння на характер руху дрібнозернистих включень. Визначено кількісну характеристику затримки частинок в області анастомозу в залежності від динамічної в'язкості рідини.

Висновки. Розглянута в даній роботі тривимірна математична модель базується на застосуванні решітчастого методу Больцмана при обчисленні гідродинамічних параметрів руху рідини в області дослідження. Особливість моделі полягає в урахуванні складного характеру рідини, яка включає дрібнозернисті включення. Модель дозволяє визначати характер поведінки цих включень та поле швидкостей $з$ достатньою точністю в реальному масштабі часу.

Ключові слова: математична модель, решітчастий метод Больцмана, моделювання анастомозу. 
Новотарский М. А. ${ }^{1}$, Стиренко С. Г. ${ }^{2}$, Гордиенко Ю. Г. ${ }^{3}$

'Д-р техн. наук, профессор кафедры вычислительной техники, Технический университет Украины «Киевский политехнический институт имени Игоря Сикорского»

${ }^{2}$ Д-р техн. наук, профессор, заведующий кафедрой вычислительной техники, Технический университет Украины «Киевский политехнический институт имени Игоря Сикорского»

${ }^{3}$ Д-р физ.-мат. наук, профессор кафедры вычислительной техники, Технический университет Украины «Киевский политехнический институт имени Игоря Сикорского»

МАТЕМАТИЧЕСКОЕ МОДЕЛИРОВАНИЕ ТРЕХМЕРНОГО НЕСТАЦИОНАРНОГО ПОТОКА ЧЕРЕЗ АНАСТОМОЗ ПИЩЕВАРИТЕЛЬНОГО ТРАКТА РЕШЕТЧАСТЫМ МЕТОДОМ БОЛЬЦМАНА

Актуальность. В последнее время существенно возросло количество реконструктивных операций на пищеварительном тракте человека. Результаты таких операций имеют прогнозируемые негативные последствия, связанные с нарушениями гидродинамических процессов в зоне анастомоза. Эти негативные последствия возможно частично устранить путем выбора формы анастомоза на основе математического моделирования. Известные математические модели являются громоздкими и не позволяют получать результаты в реальном масштабе времени. Предложенный в работе подход с использованием решетчатого метода Больцмана позволяет решить эту проблему.

Целью работы является разработка трехмерной математической модели области анастомоза для исследования с достаточной точностью гидродинамических параметров жидкости со сложной структурой в реальном масштабе времени.

Метод. Предложен метод построения и анализа математической модели анастомоза пищеварительного тракта на основе решетчатого метода Больцмана. Метод отличается тем, что обеспечивает анализ гидродинамических параметров жидкости и одновременно определяет характер движения мелкозернистых включений в зоне анастомоза. Основные этапы метода: разработка технологии задания области моделирования, дискретизация трехмерного уравнения Больцмана с выбором решетки и характера оператора коллизий, учитывающего сложную структуру жидкости, разработка технологии перехода от функции распределения плотности к распределению давления на мезоскопическом уровне с учетом особенностей свойств жидкости, переход от мезоскопических к макроскопическим параметрам жидкости.

Результаты моделирования включают определение распределения поля скоростей в зоне анастомоза с целью модификации его геометрии. Проведено исследование влияния силы тяжести на характер движения мелкозернистых включений. Определены количественные характеристики задержки частиц в области анастомоза в зависимости от динамической вязкости жидкости.

Выводы. Рассмотренная в данной работе трехмерная математическая модель базируется на применении решетчатого метода Больцмана при вычислении гидродинамических параметров движения жидкости в области исследования. Особенность модели заключается в учете сложного характера жидкости, содержащей мелкозернистые включения. Модель позволяет определять характер поведения этих включений и поле скоростей с достаточной точностью в реальном масштабе времени.

Ключевые слова: математическая модель, решетчатый метод Больцмана, моделирование анастомоза.

\section{REFERENCES}

1. Nesterenko B. B., Novotarskiy M. A. Mathematical simulation for parallel asynchronous methods of boundary value problems of mathematical physics, IMACS World Congress: 16th international conference, Lausanne, 21-25 August 2000: proceedings. Ecole Polytechnique Federale de Louzanne, 2000, pp. 116-122.

2. Rosenau $\mathrm{Ph}$. Extending hydrodynamics via the regularization of the Chapman-Enskog expansion, Physical Review A, 1989, Vol. 40, Issue 12, pp. 7193-7196. DOI: 10.1103/ PhysRevA.40.7193.

3. Temam R. Navier-stokes equations: theory and numerical analysis. Amsterdam, North-Holland, 1984, 408 p.

4. Mitchell A. R., Griffiths D. F. The finite difference method in partial differential equations. New York, John Wiley, 1980, 272 p.

5. Girault V., Rivart P.-A. Finite Element Methods for NavierStokes Equations: Theory and Algorithms. Berlin, Springer-Verlag, 1980, 375 p. DOI: 10.1007/978-3-642-61623-5.

6. Versteeg H. K., Malalasekera M. An Introduction to Computational Fluid Dynamics: The Finite Volume Method. London, Paerson education Ltd., 1995, 511 p.

7. Vilsmeier R., Benkhaldoun F., Hä nel D. Finite volumes for complex applications II: problems and perspectives. Middlesex, Hermes Science Publications, 1999, 887 p.

8. Chen S., Doolen G. Lattice Boltzmann method for fluid flows, Annual Review of Fluid Mechanics, 1998, Vol. 30, pp. 329-364. DOI: 10.1146/annurev.fluid.30.1.329.

9. Jahanshaloo L., Sidik N. A. C., Fazeli A. An overview of boundary implementation in lattice Boltzmann method for computational heat and mass transfer, International Communications in Heat and Mass Transfer, 2016, Vol. 78, Issue 11, pp. 1-12. DOI: 10.1016/j.icheatmasstransfer.2016.08.014.

10. Tan J., Sinno T., Diamond S. A parallel fluid solid coupling model using LAMMPS and Palabos based on the immersed boundary method [Electronic resource]. https://arxiv.org/abs/1704.04551.

11. Chen D. J., Lin K. H., Lin C. A. Immersed boundary method based Lattice Boltzmann method to simulate 2D and 3D complex geometry flows, International Journal of Modern Physics C, 2007, Vol. 18, Issue 4, pp. 585-594. DOI: 10.1142/ S0129183107010826.

12. Aidun C. K., Clausen J. R. Lattice-Boltzmann Method for Complex Flows, Annual Review of Fluid Mechanics, 2010, Vol. 42, Issue 1, pp. 439-472. DOI: 10.1146/annurev-fluid-121108-145519.

13. Nesterenko B. B., Novotarsky M. A. Mathematical modeling of peristaltic processes on the basis of lattice Boltzmann equation, Mathematical and Computer Modeling: Technical Sciences. Kamyanets-Podilsky, Kamianets-Podilsky National University, 2014, Issue 11, pp. 96-107.

14. Novotarsky M. A., Bronfman E. B. Simulating fluid motion in a three-dimensional area with moving boundaries, Bulletin of NTUU "KPI": Informatics, Management and Computing: Collection of scientific works. Kyiv, Vek +, 2016, Issue. 64, pp. 100-105.

15. He X., Luo L.-S. Lattice Boltzmann Model for the Incompressible Navier-Stokes Equation, Journal of Statistical Physics, 1997, Vol. 88, Issue 3, 4, pp. 927-944. DOI: 10.1023/ B:JOSS.0000015179.12689.e4.

16. Zhuchenko S. P., Nesterenko B. B. Principles of constructing a mathematical model of peristalsis of the small intestine. Kyiv, In-t mathematics, Issue 87.64, 1987, $52 \mathrm{p}$.

17. Macagno E. O., Christensen J., Lee C. L. Modeling the effect of wall movement on absorption in the intestine, Am. J. Physiol. Gastrointest Liver Physiol, 1982, Vol. 243, pp. G541-G550. 